Original Research Paper

\title{
PENINGKATKAN MOTIVASI DAN PRESTASI BELAJAR PAI MENGGUNAKAN MODEL PEMBELAJARAN PAKEM PADA SISWA KELAS VI SD MUHAMMADIYAH SUMBERMULYO BANTUL YOGYAKARTA
}

\author{
Surawan \\ Program Studi Pendidikan Agama Islam, IAIN Palangka Raya, Palangka Raya, Indonesia
}

*Corresponding Author: Surawan, Program Studi Pendidikan Agama Islam, IAIN Palangka Raya, Palangka Raya, Indonesia; Email:

sapuadi@iain-palangkaraya.ac.id

\begin{abstract}
Abstrak: Tujuan penelitian ini adalah menerapkan model pembelajaran PAKEM untuk meningkatkan motivasi dan prestasi belajar Pendidikan Agama Islam pada siswa kelas VI SD Muhammadiyah Sumbermulyo Bantul Yogyakarta Penelitian ini menggunakan penelitian tindakan (action research) sebanyak tiga siklus. Setiap putaran terdiri dari empat tahap yaitu: rancangan, kegiatan dan pengamatan, refleksi, dan revisi. Sasaran penelitian ini adalah siswa kelas VI SD Muhammadiyah Sumbermulyo, Bantul Yogyakarta dengan subjek sebanyak 22. Data yang diperoleh berupa hasil tes formatif, lembar observasi kegiatan belajar mengajar. Dari hasil analis didapatkan bahwa prestasi belajar siswa mengalami peningkatan dari siklus I sampai siklus III yaitu, siklus I (68,00\%), siklus II (80,00\%), siklus III $(92,00 \%)$. Simpulan dari penelitian ini adalah model pembelajaran PAKEM dapat berpengaruh positif terhadap motivasi belajar siswa SD Muhammadiyah Sumbermulyo, serta model pembelajaran ini dapat digunakan sebagai salah satu alternatif untuk meningkatkan prestasi belajar siswa pada pembelajaran Pendidikan Agama Islam.
\end{abstract}

Kata Kunci: PAKEM, Motivasi, Prestasi Belajar, Pendidikan Agama Islam

\section{Pendahuluan}

Kegiatan belajar mengajar dalam lingkup pendidikan memiliki peranan yang penting. Dalam proses kegiatan belajar mengajar guru dan murid terjadi kegiatan interaksi. Interaksi yang dilakukan oleh guru bertujuan menciptakan lingkungan yang bernilai edukatif demi kepentingan anak didik dalam belajar. Guru ingin memberikan layanan yang terbaik bagi anak didik, dengan menyediakan lingkungan yang menyenangkan dan menggairahkan. Guru berusaha menjadi pembimbing yang baik dengan peranan yang arif dan bijaksana, sehingga tercipta hubungan dua arah yang harmonis antara guru dengan anak didik.

Guru dituntut untuk mampu mengatasi segala kendala dalam problematika pembelajaran saat kegiatan belajar berlangsung. Semua kendala yang terjadi dapat menghambat jalannya proses belajar mengajar, baik yang berpangkal dari perilaku anak didik maupun yang bersumber dari luar anak didik, oleh karena itu kendala tersebut harus dihilangkan. Keberhasilan belajar mengajar lebih banyak ditentukan oleh guru dalam mengelola kelas (Djamarah, 2013: 60).

Keberhasilan sebuah pembelajaran ditentukan oleh banyak faktor diantaranya adalah faktor guru dalam melaksanakan proses belajar mengajar, karena guru secara langsung dapat mempengaruhi, membina dan meningkatkan kecerdasan serta keterampilan siswa. Untuk mengatasi permasalahan di atas dan guna mencapai tujuan pendidikan secara maksimal, peran guru sangat penting dan diharapkan guru mampu menyampaikan semua mata pelajaran yang tercantum dalam proses pembelajaran secara tepat dan sesuai dengan konsep-konsep mata pelajaran yang akan disampaikan. Sehingga guru memiliki peranan 
yang strategis dalam mengelola proses pembelajaran di dalam kelas. Oleh sebab itu, kemampuan guru dalam mengolah suasana kelas akan mempengaruhi kondisi siswa. Model dan media pembelajaran yang digunakan guru secara signifikan akan berdampak kepada siswa. Disinilah, peranan metode guru sangat diperlukan. Semakin kreatif seorang guru dalam menggunakan metode pembelajaran, maka akan semakin tinggi tingkat pemahaman siswa dalam menerima materi pembelajaran.

Hasil studi pendahuluan di SD Muhammadiyah Sumbermulyo menunjukkan bahwa banyak sekali siswa yang mengalami kesulitan dalam pembelajaran khususnya materi tentang sejarah Islam. Peneliti menemukan masalah terhadap siswa tersebut di antaranya: kurangnya keseriusan siswa dalam menerima pelajaran dan kurang kreatifnya dalam mengerjakan soal-soal yang diberikan guru sehingga siswa merasa sopan terhadap pelajaran tersebut. Siswa yang mencapai ketuntasan untuk mata pelajaran Pendidikan Agama Islam sebanyak 8 orang dengan nilai $\geq$ 70 atau 36,33\% dari 22 siswa. Berdasarkan kondisi tersebut maka peneliti ingin menerapkan model pembelajaran PAKEM (Pembelajaran Aktif Kreatif dan Menyenangkan) sebagai upaya untuk memperbaiki proses pembelajaran di kelas dengan tujuan untuk meningkatkan hasil belajar siswa kelas VI SD Muhammadiyah Sumbermulyo ke arah yang lebih baik.

Penerapan model ini diharapkan siswa termodtivasi yang berimplikasi terhadap peningkatan prestasi siswa. Menurut Djamarah (2013:114) motivasi adalah suatu pendorong yang mengubah energi dalam diri seseorang ke dalam bentuk aktivitas nyata untuk mencapai tujuan tertentu. Dalam proses belajar, motivasi sangat diperlukan sebab seseorang yang tidak mempunyai motivasi dalam belajar tidak akan mungkin melakukan aktivitas belajar. Hal ini sesuai dengan yang diungkapkan oleh Syah, (2017: 3) bahwa siswa yang termotivasi dalam belajar sesuatu akan menggunakan proses kognitif yang lebih tinggi dalam mempelajari materi itu, sehingga siswa itu akan menyerap dan mengendapkan materi itu dengan lebih baik.Jadi motivasi adalah suatu kondisi yang mendorong seseorang untuk berbuat sesuatu dalam mencapai tujuan tertentu.

Kualitas pembelajaran ditentukan oleh interaksi komponen-komponen dalam sistemnya. Yaitu tujuan, bahan ajar (materi), anak didik, sarana, media, metode, partisipasi masyarakat, performance sekolah, dan evaluasi pembelajaran.Performance sekolah, dan evaluasi pembelajaran (Syah, 2011: 35). Optimalisasi komponen ini, menentukan kualitas (proses dan produk) pembelajaran. Upaya yang dapat dilakukan oleh pendidik adalah melakukan analisis tentang karakteristik setiap komponen dan mensinkronisasikan sehingga ditemukan konsistensi dan keserasian di antaranya untuk tercapainya tujuan pembelajaran. Karena pembelajaran mulai dari perencana, pelaksanaan dan evaluasinya senantiasa merujuk pada tujuan yang diharapkan untuk dikuasai atau dimiliki oleh anak didik baik instructionaleffect (sesuai dengan tujuan yang dirancang) maupun nurturingeffect (dampak pengiring) (Syah: 2017: 40).

Realisasi pencapaian tujuan tersebut, terdapat kegiatan interaksi belajar mengajar terutama yang terjadi di kelas. Dengan demikian, kegiatannya adalah bagaimana terjadi hubungan antara guru/bahan ajar yang didesain dan dengan anak didik. Interaksi ini merupakan proses komunikasi penyampaian pesan pembelajaran. Hal ini sejalan dengan yang dikemukakan Sadiman yang menyatakan proses belajar mengajar pada hakekatnya adalah proses interaksi yaitu proses penyampaian pesan melalui saluran media/teknik/metode ke penerima pesan (Sardiman, 2018:13).

Model PAKEM adalah model pembelajaran yang bertumpu pada empat prinsip, yaitu: aktif, efektif, dan 
menyenangkan. Model pembelajaran ini sangat cocok untuk kurikulum 2004 berbasis kompetensi yang senantiasa berorientasi pada aktivitas siswa (student centered learning). Model ini dapat dikembangkan secara sederhana oleh guru dengan memperhatikan prinsip PAKEM. Interaksi belajar mengajarnya menuntut anak didik untuk aktif, kreatif dan senang yang melibatkan secara optimal mental dan fisik mereka. Tingkat keaktifan, kreatifitas, dan kesenangan mereka dalam belajar merupakan rentangan kontinum dari yang paling rendah sampai yang paling tinggi. Tetapi idealnya pada kontinum yang tertinggi baik pelibatan aspek mental maupun fisik anak didik. Oleh karena itu, interaksi belajar mengajar dengan paradigma PAKEM menuntut anak (1) Berbuat, (2) Terlibat dalam kegiatan, (3) Mengamati secara visual, dan (4) Mencerap informasi secara verbal.

Model PAKEM berorientasi pada proses dan tujuan. Orientasi proses dalam model PAKEM berusaha untuk meningkatkan motivasi belajar. Kemandirian dan tanggung jawab dibina sejak awal. Kebersamaan dan bekerja sama untuk mengasah emosional. Persaingan yang sehat ditumbuhkan dengan saling menghargai satu sama lain serta menumbuhkan sikap kepemimpinan. Orientasi tujuannya adalah agar anak belajar lebih mendalam, anak lebih kritis dan kreatif, suasana belajar menjadi bervariasi serta meningkatkan kematangan emosional. Tidak kalah pentingnya anak siap menghadapi perubahan dan berpartisipasi dalam proses perubahan (Usman, 2017: 50).

Kegiatan model PAKEM haruslah bervariatif dan tidak monoton. Ada beberapa yang perlu diketahui, misalnya: a. Mengamati, mengukur dan mendiskrip-sikan, b. Mengajukan pertanyaan dan mencatat, $c$. Berdiskusi, berdebat, dan membuat rangkuman, d. Merencanakan dan melakukan percobaan, e. Melaporkan, mempresentasikan, bermain peran, membuat puisi atau hasil karya lain dan memajangkan (Usman, 2017: 32). Dengan demikian, interaksi belajar mengajar idealnya mampu membelajarkan anak didik berdasarkan problem based learning, authentic instruction, inquiry based learning, project based learning, service learning, and cooperative learning. Pola interaksi yang mampu mengemas hal tersebut dapat mengubah paradigma pembelajaran aktif menjadi paradigma pembelajaran reflektif. Interaksi pembelajaran reflektif dapat membuat anak didik untuk menjadikan hasil belajar sebagai referensi refleksi kritis tentang dampak ilmu pengetahuan dan teknologi terhadap masyarakat; mengasah kepedulian sosial, mengasah hati nurani, dan bertanggungjawab terhadap karirnya kelak. Kemampuan ini dimiliki anak didik, karena dengan pola interaksi pembelajaran tersebut, dapat membuat anak didik aktif dalam berfikir (mind-on), aktif dalam berbuat (hand-on), mengembangkan kemampuan bertanya, mengembangkan kemampuan berkomuni-kasi, dan membudayakan untuk memecah-kan permasalahan baik secara personal maupun sosial.

Seorang guru agar berhasil secara optimal, maka dituntut untuk mengubah peran dan fungsinya menjadi fasilitator, mediator, mitra belajar anak didik, dan evaluator. Ini berarti, guru harus menciptakan interaksi pembelajaran yang demokratis dan dialogis antara guru dengan anak didik, dan anak didik dengan anak didik (Djamarah, 2013: 20). Dengan interaksi pembelajaran yang mengemas nilai-nilai tersebut dapat membuat pembelajaran lingking (link and math atau life skill) dan delinking (pemutusan lingkungan negatif), diversifi-kasi kurikulum, pembelajaran kontekstual, kurikulum berbasis kompetensi, dan otonomi pendidikan pada tingkat sekolah taman kanak-kanak dengan manajemen berbasis sekolah, dan bertujuan untuk mengupayakan fondasi dan mengembang-kan anak untuk memiliki kemampuan yang utuh yang disebut: Pendidikan Anak Seutuhnya (PAS). 


\section{Metode}

Penelitian ini merupakan penelitian tindakan (action research), karena penelitian dilakukan untuk memecahkan masalah pembelajaran di kelas. Penelitian ini juga termasuk penelitian deskriptif, sebab menggambarkan bagaimana suatu teknik pembelajaran diterapkan dan bagaimana hasil yang diinginkan dapat dicapai. Menurut Sukidin et al (2010: 54) ada 4 macam bentuk penelitian tindakan, yaitu: (1) penelitian tindakan guru sebagai peneliti, (2) penelitian tindakan kolaboratif, (3) penelitian tindakan simultan terintegratif, dan (4) penelitian tindakan sosial eksperimental.

Keempat bentuk penelitian tindakan di atas, ada persamaan dan perbedaannya. Menurut Oja dan Smulyan sebagaimana dikutip oleh Sukidin (2010: 55), ciri-ciri dari setiap penelitian tergantung pada: (1) tujuan utamanya atau pada tekanannya, (2) tingkat kolaborasi antara pelaku peneliti dan peneliti dari luar, (3) proses yang digunakan dalam melakukan penelitian, dan (4) hubungan antara proyek dengan sekolah. Dalam penelitian ini menggunakan bentuk guru sebagai peneliti, dimana guru sangat berperan sekali dalam proses penelitian tindakan kelas. Dalam bentuk ini, tujuan utama penelitian tindakan kelas ialah untuk meningkatkan praktik-praktik pembelajaran di kelas. Dalam kegiatan ini, guru terlibat langsung secara penuh dalam proses perencanaan, tindakan, observasi, dan refleksi. Kehadiran pihak lain dalam penelitian ini peranannya tidak dominan dan sangat kecil.

Penelitian ini mengacu pada perbaikan pembelajaran yang berkesinambungan. Suharsimi (2013: 23) menyatakan bahwa model penelitian tindakan adalah berbentuk spiral. Tahapan penelitian tindakan pada suatu siklus meliputi perencanaan atau pelaksanaan observasi dan refleksi. Siklus ini berlanjut dan akan dihentikan jika sesuai dengan kebutuhan dan dirasa sudah cukup.
Tempat penelitian adalah tempat yang digunakan dalam melakukan penelitian untuk memperoleh data yang diinginkan. Penelitian ini bertempat di SD Muhammadiyah Sumbermulyo, Bantul, Yogyakarta Tahun pelajaran 2017/2018. Waktu penelitian adalah waktu berlangsungnya penelitian atau saat penelitian ini dilangsungkan. Penelitian ini dilaksanakan pada bulan Februari semester genap. Subyek penelitian adalah siswa-siswi kelas VI tahun pelajaran 2017/2018 pada pokok bahasan kisah nabi Ibrahim a.s, dan nabi Ismail a.s.

Alat pengumpul data dalam penelitian ini adalah tes buatan guru yang fungsinya adalah: (1) untuk menentukan seberapa baik siswa telah menguasai bahan pelajaran yang diberikan dalam waktu tertentu, (2) untuk menentukan apakah suatu tujuan telah tercapai, dan (3) untuk memperoleh suatu nilai (Arikunto, Suharsimi, 2013: 149). Sedangkan tujuan dari tes adalah untuk mengetahui ketuntasan belajar siswa secara individual maupun secara klasikal. Samping dilakukan untuk mengetahui letak kesalahan-kesalahan yang dilakukan siswa sehingga dapat dilihat dimana kelemahannya, khususnya pada bagian mana TPK yang belum tercapai. Untuk memperkuat data yang dikumpulkan maka juga digunakan metode observasi (pengamatan) yang dilakukan oleh teman sejawat untuk mengetahui dan merekam aktivitas guru dan siswa dalam proses belajar mengajar.

Teknik analisis data yang digunakan adalah kuantitatif deskriptif. Cara penghitungan untuk mengetahui ketuntasan belajar siswa dalam proses belajar mengajar sebagai berikut. Menghitung jumlah skor yang tercapai dan prosentasenya untuk masing-masing siswa dengan menggunakan rumus ketuntasan belajar seperti yang terdapat dalam buku petunjuk teknis penilaian yaitu siswa dikatakan tuntas secara individual jika mendapatkan nilai minimal 65, sedangkan secara klasikal dikatakan tuntas belajar jika jumlah siswa yang tuntas secara individu mencapai $85 \%$ yang 
telah mencapai daya serap lebih dari sama dengan 65\%. Menganalisa hasil observasi yang dilakukan oleh guru sendiri selama kegiatan belajar mengajar berlangsung.

\section{Hasil dan Pembahasan}

\section{Siklus I}

Perencanaan pada siklus I ini peneliti mempersiapkan perangkat pembelaja-ran yang terdiri dari rencana pelajaran 1, soal tes formatif 1 dan alat-alat pengajaran yang mendukung. Selain itu juga dipersiapkan lembar observasi pengelolaan model pembelajaran PAKEM, dan lembar observasi aktivitas guru dan siswa.

Pelaksanaan kegiatan belajar mengajar untuk siklus I dilaksanakan pada tanggal 6 Februari 2018 di Kelas VI jumlah siswa 22 siswa. Dalam hal ini peneliti bertindak sebagai pengajar. Adapun proses belajar mengajar mengacu pada rencana pelajaran yang telah dipersiapkan. Pengamatan (observasi) dilaksanakan bersamaan dengan pelaksanaan belajar mengajar. Pada akhir proses belajar mengajar siswa diberi tes formatif I dengan tujuan untuk mengetahui tingkat keberhasilan siswa dalam proses belajar mengajar yang telah dilakukan. Adapun data hasil penelitian pada siklus I terlihat pada Tabel 1:

Tabel 1. Rekapitulasi Hasil Tes Formatif Siswa Pada Siklus I

\begin{tabular}{clc}
\hline No & \multicolumn{1}{c}{ Uraian } & Siklus \\
\hline 1. & Nilai rata-rata tes formatif & 70 \\
2. & $\begin{array}{l}\text { Jumlah siswa yang tuntas } \\
\text { belajar }\end{array}$ & 15 \\
3. & $\begin{array}{l}\text { Persentase ketuntasan } \\
\text { belajar }\end{array}$ & 68,18 \\
\hline
\end{tabular}

Berdasarkan Tabel 1 dapat dijelaskan bahwa dengan menerapkan pembelajaran model PAKEM diperoleh nilai rata-rata prestasi belajar siswa adalah 70,00 dan ketuntasan belajar mencapai $68,18 \%$ atau ada 15 siswa dari 22 siswa sudah tuntas belajar. Hasil tersebut menunjukkan bahwa pada siklus pertama secara klasikal siswa belum tuntas belajar, karena siswa yang memperoleh nilai 65 hanya sebesar 68,18\% lebih kecil dari persentase ketuntasan yang dikehendaki yaitu sebesar $85 \%$. Hal ini disebabkan karena siswa masih merasa baru dan belum mengerti apa yang dimaksudkan dan digunakan guru dengan menerapkan pembelajaran model PAKEM.

Refleksi pelaksanaan kegiatan belajar mengajar pada siklus I diperoleh informasi dari hasil pengamatan sebagai berikut (1) Guru kurang maksimal dalam memotivasi siswa dan dalam menyampaikan tujuan pembelajaran, (2) Guru kurang maksimal dalam pengelolaan waktu. (3) Siswa kurang aktif selama pembelajaran berlangsung.

Pelaksanaan kegiatan belajar mengajar pada siklus I ini masih terdapat kekurangan, sehingga perlu adanya revisi untuk dilakukan pada siklus berikutnya (1) Guru perlu lebih terampil dalam memotivasi siswa dan lebih jelas dalam menyampaikan tujuan pembelajaran. Dimana siswa diajak untuk terlibat langsung dalam setiap kegiatan yang akan dilakukan. (2) Guru perlu mendistribusikan waktu secara baik dengan menambahkan informasi-informasi yang dirasa perlu dan memberi catatan. (3) Guru harus lebih terampil dan bersemangat dalam memotivasi siswa sehingga siswa bisa lebih antusias.

\section{Siklus II}

Perencanaan pada siklus ini peneliti telah mempersiapkan perangkat pembelaja-ran yang terdiri dari rencana pelajaran 2 , soal tes formatif 2 dan alat-alat pengajaran yang mendukung. Pelaksanaan kegiatan belajar mengajar untuk siklus II dilaksanakan pada tanggal 14Februari 2018 di Kelas VI dengan jumlah siswa 22 siswa. Dalam hal ini peneliti bertindak sebagai pengajar. Adapun proses belajar mengajar mengacu pada rencana pelajaran dengan memperhatikan revisi pada siklus I, sehingga kesalahan atau kekurangan pada siklus I tidak terulang lagi pada siklus II. Pengamatan (observasi) dilaksanakan bersamaan dengan pelaksanaan belajar 
mengajar. Padaakhir proses belajar mengajar siswa diberi tes formatif II dengan tujuan untuk mengetahui tingkat keberhasilan siswa dalam proses belajar mengajar yang telah dilakukan. Instrumen yang digunakan adalah tes formatif II. Adapun data hasil penelitian pada siklus II adalah seperti terlihat pada Tabel 2 .

Tabel 2. Rekapitulasi Hasil Tes Formatif Siswa Pada Siklus II

\begin{tabular}{clc}
\hline No & \multicolumn{1}{c}{ Uraian } & Siklus \\
\hline 1. & Nilai rata-rata tes formatif & 77,73 \\
2. & Jumlah siswa yang tuntas belajar & 17 \\
3. & Persentase ketuntasan belajar & 79,01 \\
\hline
\end{tabular}

Berdasarkan Tabel 2 di atas diperoleh nilai rata-rata prestasi belajar siswa adalah 77,73 dan ketuntasan belajar mencapai $79,01 \%$ atau ada 17 siswa dari 22 siswa sudah tuntas belajar. Hasil ini menunjukkan bahwa pada siklus II ini ketuntasan belajar secara klasikal telah mengalami peningkatan sedikit lebih baik dari siklus I. Adanya peningkatan hasil belajar siswa ini karena setelah guru menginformasikan bahwa setiap akhir pelajaran akan selalu diadakan tes sehingga pada pertemuan berikutnya siswa lebih termotivasi untuk belajar. Selain itu siswa juga sudah mulai mengerti apa yang dimaksudkan dan diinginkan guru dengan menerapkan pembelajaran model PAKEM.

Refleksi pelaksanaan kegiatan belajar pada siklus II diperoleh informasi dari hasil pengamatan sebagai berikut (1) Memotivasi siswa, (2) Membimbing siswa merumuskan kesimpulan/ menemukan konsep,

Pengelolaan waktu. Pelaksanaan kegiatan belajar pada siklus II ini masih terdapat kekurangan-kekurangan. Maka perlu adanya revisi untuk dilaksanakan pada siklus II antara lain (1) Guru dalam memotivasi siswa hendaknya dapat membuat siswa lebih termotivasi selama proses belajar mengajar berlangsung. (2) Guru harus lebih dekat dengan siswa sehingga tidak ada perasaan takut dalam diri siswa baik untuk mengemukakan pendapat atau bertanya. (3) Guru harus lebih sabar dalam membimbing siswa merumuskan kesimpulan/menemukan konsep. (4) Guru harus mendistribusikan waktu secara baik sehingga kegiatan pembelajaran dapat berjalan sesuai dengan yang diharapkan. (5) Guru sebaiknya menambah lebih banyak contoh soal dan memberi soal-soal latihan pada siswa untuk dikerjakan pada setiap kegiatan belajar mengajar.

\section{Siklus III}

Tahap perencanaan pada siklus III ini telah dipersiapkan perangkat pembelaja-ran yang terdiri dari rencana pelajaran 3 , soal tes formatif 3 dan alat-alat pengajaran yang mendukung. Pelaksanaan kegiatan belajar mengajar untuk siklus III dilaksanakan pada tanggal 22Februari 2018 di Kelas VI dengan jumlah siswa 22 siswa. Dalam hal ini peneliti bertindak sebagai pengajar. Adapun proses belajar mengajar mengacu pada rencana pelajaran dengan memperhatikan revisi pada siklus II, sehingga kesalahan atau kekurangan pada siklus II tidak terulang lagi pada siklus III. Pengamatan (observasi) dilaksanakan bersamaan dengan pelaksanaan belajar mengajar. Pada akhir proses belajar mengajar siswa diberi tes formatif III dengan tujuan untuk mengetahui tingkat keberhasilan siswa dalam proses belajar mengajar yang telah dilakukan. Instrumen yang digunakan adalah tes formatif III. Adapun data hasil penelitian pada siklus III adalah tertera pada Tabel 3.

Tabel 3. Hasil Formatif Siswa Pada Siklus III

\begin{tabular}{clc}
\hline No & \multicolumn{1}{c}{ Uraian } & Siklus \\
\hline 1. & Nilai rata-rata tes formatif & 82,73 \\
2. & Jumlah siswa yang tuntas belajar & 19 \\
3. & Persentase ketuntasan belajar & 86,36 \\
\hline
\end{tabular}

Berdasarkan tabel di atas diperoleh nilai ratarata tes formatif sebesar 82,73 dan dari 22 siswa telah tuntas sebanyak 19 siswa dan 3 siswa belum mencapai ketuntasan belajar. Maka secara klasikal ketuntasan belajar yang telah tercapai sebesar 86,36\% (termasuk kategori tuntas). Hasil pada siklus III ini mengalami peningkatan lebih baik dari siklus II. Adanya peningkatan hasil belajar pada siklus III ini dipengaruhi oleh adanya 
peningkatan kemampuan guru dalam menerapkan pembelajaran model PAKEM sehingga siswa menjadi lebih terbiasa dengan pembelajaran seperti ini sehingga siswa lebih mudah dalam memahami materi yang telah diberikan.

Kegiatan yang telah dilakukan pada tahap refleksi III adalah mengkaji apa yang telah terlaksana dengan baik maupun yang masih kurang baik dalam proses belajar mengajar dengan penerapan pembelajaran model PAKEM. Data-data yang telah diperoleh dapat diuraikan sebagai berikut: (1) Selama proses belajar mengajar guru telah melaksanakan semua pembelajaran dengan baik. Meskipun ada beberapa aspek yang belum sempurna, tetapi persentase pelaksanaannya untuk masing-masing aspek cukup besar. (2) Berdasarkan data hasil pengamatan diketahui bahwa siswa aktif selama proses belajar berlangsung. (3) Kekurangan pada siklus-siklus sebelumnya sudah mengalami perbaikan dan peningkatan sehingga menjadi lebih baik. (4) Hasil belajar siswa pada siklus III mencapai ketuntasan.

Hasil refleksi pada siklus III bahwa guru telah menerapkan pembelajaran model PAKEM dengan baik dan dilihat dari aktivitas siswa serta hasil belajar siswa pelaksanaan proses belajar mengajar sudah berjalan dengan baik. Maka tidak diperlukan revisi terlalu banyak, tetapi yang perlu diperhatikan untuk tindakan selanjutnya adalah memaksimalkan dan mempertahankan apa yang telah ada dengan tujuan agar pada pelaksanaan proses belajar mengajar selanjutnya penerapan model pembelajaran PAKEM dapat meningkatkan proses belajar mengajar sehingga tujuan pembelajaran dapat tercapai.

Hasil penelitian ini menunjukkan bahwa pembelajaran model PAKEM memiliki dampak positif dalam meningkatkan prestasi belajar siswa. Hal ini dapat dilihat dari semakin mantapnya pemahaman siswa terhadap materi yang disampaikan guru (ketuntasan belajar meningkat dari siklus I, II, dan III) yaitu masing-masing 68,18\%, 79,01\%, dan $86,36 \%$. Pada siklus III ketuntasan belajar siswa secara klasikal telah tercapai. Melalui model pembelajaran PAKEM, siswa aktif baik secara fisik dan mental seperti bertanya dan mengungkapkan gagasan (Fahmi, 2013; Ainak, 2009). Lebih lanjut hasil penelitian Sumartono (2013) menunjukkan bahwa model pembelajaran PAKEM memberikan pengaruh sebesar $45,98 \%$.

Hasil analisis data aktivitas siswa dalam proses pembelajaran PAKEM bahwa aktivitas siswa dalam proses belajar mengajar dengan menerapkan model pembelajaran PAKEM dalam setiap siklus mengalami dalam penelitian ini menunjukkan peningkatan. Hal ini berdampak positif terhadap prestasi belajar siswa yaitu dapat ditunjukkan dengan meningkatnya nilai rata-rata siswa pad setiap siklus yang terus mengalami peningkatan. Berdasarkan analisis data, diperoleh aktivitas siswa dalam proses pembelajaran PAI pada pokok bahasan kisah nabi Ibrahim a.s, dan nabi Ismail a.s dengan model pembelajaran PAKEM yang paling dominan adalah, mendengarkan/memperhatikan penjelasan guru, dan diskusi antar siswa/antara siswa dengan guru. Jadi dapat dikatakan bahwa aktivitas siswa dapat dikategorikan aktif.

Aktivitas guru selama pembelajaran telah melaksanakan langkah-langkah kegiatan belajar mengajar dengan menerapkan pengajaran konstekstual model pengajaran berbasis masalah dengan baik. Hal ini terlihat dari aktivitas guru yang muncul di antaranya aktivitas membimbing dan mengamati siswa dalam menemukan konsep, menjelaskan materi yang sulit, memberi umpan balik/evaluasi/tanya jawab dimana prosentase untuk aktivitas di atas cukup besar.

\section{Kesimpulan}

Berdasarkan hasil penelitian yang telah dipaparkan selama tiga siklus, hasil seluruh pembahasan serta analisis yang telah dilakukan 
dapat disimpulkan sebagai berikut: (1) Penerapan pembelajaran model PAKEM mempunyai pengaruh positif, yaitu dapat meningkatkan motivasi belajar siswa. (2) Pembelajaran model PAKEM memiliki dampak positif dalam meningkatkan prestasi belajar siswa yang ditandai dengan peningkatan ketuntasan belajar siswa dalam setiap siklus, yaitu siklus I $(68,18 \%)$, siklus II $(79,01 \%)$, siklus III (86,36\%). (3) Model pembelajaran PAKEM dapat menjadikan siswa merasa dirinya mendapat perhatian dan kesempatan untuk menyampaikan pendapat, gagasan, ide dan pertanyaan. (4) Siswa dapat bekerja secara mandiri maupun kelompok, serta mampu mempertanggungjawabkan segala tugas individu maupun kelompok.

\section{Saran}

Beradasarkan hasil penelitian yang diperoleh dari uraian sebelumnya agar proses belajar mengajar PAI lebih efektif dan lebih memberikan hasil yang optimal bagi siswa, maka disampaikan saran sebagai berikut: (1) PTK yang dilaksanakan peneliti belum sempurna. Hal ini dapat dilanjutkan oleh rekanrekan berikutnya. (2) Guru di SD Muhammadiyah Sumbermulyo khususnya kelas VI dapat menerapkan metode pembelajaran PAKEM pada mata pelajaran PAI. (3) Bagi guru lainnya terutama di Bambanglipuri Bantul dapat menerapkan hasil penelitian yang dilakukan melalui PTK.

\section{Daftar Pustaka}

Ainak, R. (2009). Implementasi Pembelajaran Bahasa Arab Model Pembelajaran Aktif, Kreatif, Efektif, dan Menyenangkan (PAKEM) di Madrasah Ibtidaiyah Sunan Pandanaran, Ngaglik, Sleman. Unpublished Paper. Yogyakarta: UIN [Universitas Islam Negeri] Sunan Kalijaga.
Arikunto, S. 2013. Dasar-dasar Evaluasi Pendidikan. Jakarta: Bumi Aksara.

Arikunto, S. 2013. Prosedur Penelitian Suatu Pendekatan Praktek. Jakarta: Rineksa Cipta.

Azhar, L.M. 1993. Proses Belajar Mengajar Pendidikan. Jakarta: Usaha Nasional.

Djamarah, S.B. 2013. Strategi Belajar Mengajar. Jakarta: Rineksa Cipta.

Djamarah, S.B. 2011. Psikologi Belajar. Jakarta: Rineksa Cipta (cet ke-3).

Fahmi, Z. (2013). Indikator pembelajaran aktif dalam konteks Pengimplementasian pendekatan pembelajaran aktif, kreatif, Efektif, dan menyenangkan (PAKEM). AlTa lim Journal, 20(1), 278-284.

Sardiman, A.M. 2018. Interaksi dan Motivasi Belajar Mengajar. Jakarta: Bina Aksara.

Sumartono, T. (2013). Penerapan model pembelajaran aktif, kreatif, efektif dan menyenangkan (PAKEM) terhadap hasil belajar passing bawah bolavoli (Studi pada siswa kelas X SMA Negeri 1 Singgahan Tuban). Jurnal Pendidikan Olahraga dan Kesehatan, 1(2).

Sukidin, dkk. 2010. Manajemen Penelitian Tindakan Kelas. Surabaya: Insan Cendekia.

Syah, Muhiddin 2017. Psikologi Pendidikan, Suatu Pendekatan Baru. Bandung: Remaja Rosdakarya.

Usman, M.U. 2017. Menjadi Guru Profesional. Bandung: Remaja Rosdakarya. 